\title{
Enzyme additives influence bacterial communities of Medicago sativa silage as determined by Illumina sequencing
}

\author{
Zongfu Hu${ }^{1,2}$, Deying Ma ${ }^{1 *}$, Huaxin Niu², Jie Chang ${ }^{2}$, Jianhua Yu' ${ }^{1}$, Qing Tong ${ }^{1}$ and Shuguo Li ${ }^{2}$
}

\begin{abstract}
The goal of the present study was to evaluate the effects of enzymes (cellulase combined with galactosidase) and their combination with Lactobacillus plantarum (LP) on bacterial diversity in alfalfa silages using high-throughput sequencing. Alfalfa forages were treated with or without cellulase + a-galactosidase (CEGA), cellulase + LP (CELP), or a-galactosidase + LP (GALP). After 56 days of ensiling, all treated silages exhibited improved fermentation quality, as reflected by decreased $\mathrm{pH}$, ammonium- $\mathrm{N}$ and increased lactic acid levels compared to the control silage $(P<0.05)$. Enzymatic treatment improved nutrient value by increasing crude protein levels and decreasing neutral detergent fibre (NDF) levels $(P<0.05)$. Silage treatment significantly altered the bacterial community, as determined by PCoA $(P<0.05)$. Lactic acid bacteria (LAB) dominated the bacterial community of the treated silage after ensiling. The dominant bacteria changed from Garciella, Enterococcus, Lactobacillus and Pediococcus in the control silage to Lactobacillus and Pediococcus in the CEGA silage and Lactobacillus in the CELP and GALP silages. Collectively, these results suggest that treatment with both enzymes alone and in combination with inoculants greatly increased the abundance of LAB, with Enterococcus, Lactobacillus and Pediococcus observed in the silage treated with enzymes alone (CEGA) and Lactobacillus observed in the silage treated with a combination of enzymes and inoculants (CELP and GALP).
\end{abstract}

Keywords: Illumina sequencing, Bacterial community, Cellulase, a-Galactosidase, L. plantarum, Alfalfa silage

\section{Introduction}

Alfalfa is a major forage for animal feed and is widely used worldwide. Due to the substantial dry matter (DM) loss that occurs during the hay-making process, ensiling is an efficient method for preserving the nutritive value of alfalfa (Oliveira et al. 2017; Muck et al. 2018). The efficient growth of LAB under anaerobic conditions can lead to the production of organic acids, inhibition of spoilageassociated bacterial and fungal growth, and the efficient preservation of silage nutrients, but a variety of epiphytic natural microbes affect fermentation (McDonald 1991).

In addition to bacterial inoculants, enzymes such as cellulase, hemicellulase, pectinase, and amylase

\footnotetext{
*Correspondence: madeying@neau.edu.cn

${ }^{1}$ College of Animal Science and Technology, Northeast Agricultural

University, Harbin, People's Republic of China

Full list of author information is available at the end of the article
}

(Tengerdy et al. 2010; Kozelov et al. 2008) are extensively used in the ensiling process (Muck et al. 2018; Dunière et al. 2013). The most commonly used enzymes are cellulases, which are widely recognized for their applications in forage preservation (Arriola et al. 2011; ContrerasGovea et al. 2011). These enzymes used for ensiling have the ability to degrade cell walls and release soluble sugars, which are essential substrates for LAB growth (Muck et al. 2018). The cleavage of $\beta$-(1,4)-linkages in cellulose by cellulase can release polysaccharides followed by glucose, decreasing the neutral detergent fibre (NDF) and acid detergent fibre (ADF) contents of silage (Nadeau et al. 2000). Previous studies have shown that treating silage with enzymes (cellulase, amylase, and pectinase) can increase lactate levels and decrease ammonia-N levels by $40 \%$ (Sheperd et al. 1995). A study by Selmer-Olsen et al. (1993) showed that cellulase/hemicellulase enzymes improve the silage quality of perennial ryegrass (Lolium
Springer Open (c) The Author(s) 2021. This article is licensed under a Creative Commons Attribution 4.0 International License, which permits use, sharing, adaptation, distribution and reproduction in any medium or format, as long as you give appropriate credit to the original author(s) and the source, provide a link to the Creative Commons licence, and indicate if changes were made. The images or other third party material in this article are included in the article's Creative Commons licence, unless indicated otherwise in a credit line to the material. If material is not included in the article's Creative Commons licence and your intended use is not permitted by statutory regulation or exceeds the permitted use, you will need to obtain permission directly from the copyright holder. To view a copy of this licence, visit http://creativeco mmons.org/licenses/by/4.0/. 
perenne) and Italian ryegrass (Lolium multiflorum) and delay aerobic deterioration.

Currently, little research has been performed on the use of galactosidase as an additive in silage. Galactosidase, which is typically isolated from microbes (such as lactobacilli, fungi and yeasts), can act upon a variety of sugars, such as melibiose, raffinose and stachyose, by hydrolysing the (1-6) galactosidic bonds of these sugars to release glucose, which can be utilized by LAB (Mital et al. 1973; Garro et al. 1996). The glycosides raffinose, stachyose and saponin are present in alfalfa (Cunningham et al. 2003). Most glycosides are antinutritional factors (ANFs) for animals, which can inhibit the digestion and absorption of nutrients in animals and even cause poisoning. Saponins are the primary ANFs in alfalfa, and high levels of approximately 40 types of saponins, such as medicagenic acid, hederagenin, bayogenin, and soy saponins are present in alfalfa (Kiełbasa et al. 2019). The common sugars that make up saponins include glucose, galactose, rhamnose, arabinose, xylose and other pentose sugars (Pecetti et al. 2010; Tava and Odoardi 1996; Rafińska et al. 2017). The ability to hydrolyse a-galactosidase aids in the removal of ANFs. Furthermore, the hydrolysis of this saponin to monose, such as glucose or pentose, can promote the growth of $\mathrm{LAB}$ and improve the fermentation quality of alfalfa silage.

Bacterial community composition is important for the fermentation quality of silage. To date, several studies have investigated the bacterial community of silage treated with inoculants, such as, Lactobacillus plantarum, and Lactobacillus buchneri (Drouin et al. 2019; Zheng et al. 2017; Guo et al. 2018; Yang et al. 2019). However, the effects of enzyme treatment and further treatment with enzyme + inoculants on silage microbiota have not been investigated and remain unknown. Therefore, the objective of the present study was to investigate the differences in the bacterial communities in alfalfa silage treated with enzymes, inoculants and their combinations. Using the Illumina MiSeq platform, we characterized the bacterial community of alfalfa silage inoculated without and with cellulase plus a-galactosidase (CEGA), cellulase plus LP (CELP), and a-galactosidase plus LP (GALP).

\section{Materials and methods}

\section{Sample preparation and collection}

Alfalfa (50\% bloom stage) was harvested at the second cut from fields located at the University of Inner Mongolia for Nationalities $\left(\mathrm{E} 122^{\circ} 15^{\prime}, \mathrm{N} 43^{\circ} 38^{\prime}\right)$, Inner Mongolia, on June 22, 2017. The alfalfa was wilted to obtain a DM content of approximately $37 \%$ in a ventilated room and then chopped to a length of $10 \mathrm{~mm}$ with a forage cutter. The forage was treated as follows: (1) control with no additives; (2) cellulase (20,000 IU/g, SD-124, Challenge
Co., Ltd., Beijing, China) plus a-galactosidase (15,000 IU, SD-124, Challenge Co., Ltd., Beijing, China) (CEGA) at a dose of $5 \mathrm{~g} / \mathrm{kg}$ fresh forage for each enzyme; (3) cellulase at a dose of $5 \mathrm{~g} / \mathrm{kg}$ forage combined with $1 \times 10^{7} \mathrm{cfu} / \mathrm{g} \mathrm{FM}$ of freshly cultured L. plantarum (BNCC337987, Bnbio Co., Ltd., Beijing, China) (CELP); and 4) a-galactosidase at a dose of $5 \mathrm{~g} / \mathrm{kg}$ forage, combined with $1 \times 10^{7} \mathrm{cfu} / \mathrm{g}$ FM of L. plantarum (GALP). During the preparation of silage, the additives were applied to the forage as a solution $(20 \mathrm{ml} / \mathrm{kg} \mathrm{FM})$, and untreated silage was sprayed with equal amounts of sterile water. Five hundred grams of the forage was sealed in polyethylene silo bags using a vacuum sealer (BH 950, Matsushita, Tokyo, Japan) to remove the air. Twelve vacuum-bag mini-silos were prepared, with 3 repetitions performed for each treatment. Ensiling was performed at room temperature $\left(26^{\circ} \mathrm{C}\right)$ for 56 days.

\section{Chemical analyses and microbial enumeration}

The fresh forage ( 0 sample) and all silage samples were analysed for their chemical characteristics. The DM levels of the samples were determined in a forced-air oven at $60{ }^{\circ} \mathrm{C}$ for $48 \mathrm{~h}$. The ammonia- $\mathrm{N}\left(\mathrm{NH}_{3}-\mathrm{N}\right)$ content was measured as described by Zahiroddini et al. (2004). The water-soluble carbohydrate (WSC) content was measured according to Owens et al. (1999). To obtain the silage extract, $20 \mathrm{~g}$ of each sample was mixed with $180 \mathrm{~mL}$ of deionized water. After overnight incubation at $4{ }^{\circ} \mathrm{C}$, the sample was shaken for $2 \mathrm{~min}$ and then filtered through coarse $(20-25 \mu \mathrm{m}$ particle retention) filter paper. Silage $\mathrm{pH}$ and the levels of ammonia-N and organic acids (lactic, acetic, propionic, and butyric acids) were measured using the water extracts of the silages (Kung et al. 2003). Organic acid levels were measured by HPLC on an Agilent 1100 system (Agilent, Palo Alto, CA, USA) equipped with a UV detector $(210 \mathrm{~nm})$ and a column (ICSep COREGEL-87H). The mobile phase was $0.005 \mathrm{M} \mathrm{H}_{2} \mathrm{SO}_{4}$ at a flow rate of $0.6 \mathrm{~mL} / \mathrm{min}$ at $55^{\circ} \mathrm{C}(\mathrm{Ni}$ et al. 2017). The NDF and ADF levels were measured as described by van Soest et al. (1991). The crude protein (CP) content was measured using the Kjeldahl N method and calculated as Kjeldahl $\mathrm{N} \times 6.25$ (AOAC 2000). LAB was enumerated by plate counting on de Man, Rogosa and Sharpe (MRS) agar.

\section{DNA extraction and Illumina sequencing}

Microbial DNA was extracted from raw silage samples using a FastDNA SPIN Soil Kit (MP Biomedicals, Santa Ana, CA, USA). In brief, silage (approximately $0.3-0.4 \mathrm{~g}$ wet weight for each sample) was first added to a $2 \mathrm{ml}$ lysing matrix tube added with homogenizing reagent provided by kit, then employed a series of lysing, homogenizing, and DNA purification and elution procedure 
following the manufacturer's instructions. DNA quality was checked by $1 \%$ agarose gel electrophoresis and spectrophotometry (NanoDrop 2000, Thermo Scientific, Waltham, MA, USA; $260 / 280 \mathrm{~nm}$ optical density ratios). PCR was used to amplify the variable (V3-V4) region of the 16S rRNA genes using 12-bp barcoded primers (forward 338F: 5'-ACTCCTACGGGAGGCAGCA-3'; reverse 806R: 5'-GGACTACHVGGGTWTCTAAT$\left.3^{\prime}\right)$. PCR products were extracted from a $2 \%$ agarose gel and purified with a AxyPrep DNA Gel Extraction Kit (Axygen Biosciences, Union City, CA, USA). Finally, the cloned libraries were pooled in equimolar amounts and sequenced on the Illumina MiSeq PE300 platform (Illumina Corporation, San Diego, CA, USA) at Shanghai Majorbio Bio-Pharm Technology Co., Ltd. (Shanghai, China).

The sequence data for all samples were deposited in the NCBI Sequence Read Archive (SRA) under BioProject number PRJNA522947.

\section{Bioinformatics analysis}

After sequencing, the fastq files for each sample were generated. Paired-end sequences were merged by their overlapping regions with overlaps of $>10$ bp using Trimmomatic (Bolger et al. 2014). QIIME (Caporaso et al. 2010) was used to perform quality control. Usearch (version 7.1) (Edgar et al. 2011) was used to identify operational taxonomic units (OTUs) based on 97\% sequence identity and check the sequence quality. The representative sequences obtained for each OTU were compared with Silva 132 (http://www.arb-silva.de) to obtain taxonomic information with RDP Classifier (version 2.2, http://sourceforge.net/projects/rdp-classifier/).

a-Diversity indices (Shannon, Simpson, Chao, and Ace) were determined with mothur software (version v.1.30.1) (Schloss et al. 2009). Non-metric multidimensional scaling (NMDS) analysis was performed to evaluate the $\beta$-diversity distance matrix, and Adonis analysis was performed to test the reliability of the NMDS clusters using QIIME. Redundancy analysis (RDA) was conducted in the $R$ vegan package using Monte Carlo permutation (999 repetitions).

\section{Statistical analysis}

All data from chemical determinations, and microbial counts (transformed to $\log 10$ ) were evaluated by oneway analysis of variance using SPSS 19.0 (SPSS, Chicago,
IL, USA), with the different treatments of alfalfa silages were regarded as the fixed effect. Using the calculated means, the data were further compared with Tukey's test at the $5 \%$ significance level. All data are presented as the mean \pm standard error of triplicate groups.

\section{Results}

\section{Chemical composition}

The DM content, $\mathrm{pH}, \mathrm{WSC}$, ammonia, crude protein, $\mathrm{NDF}$, and ADF values of alfalfa forage prior to ensiling were $36.92 \%, 6.13,69.23 \mathrm{~g} / \mathrm{kg} \mathrm{DM}, 4.58 \mathrm{~g} / \mathrm{kg}$ DM, $24.62 \mathrm{~g} /$ $\mathrm{kg} \mathrm{DM}, 47.64 \mathrm{~g} / \mathrm{kg} \mathrm{DM}$, and $36.73 \mathrm{~g} / \mathrm{kg} \mathrm{DM}$, respectively. The number of detected LAB was $6.37 \mathrm{log} \mathrm{cfu} / \mathrm{g}$ FM (Table 1).

Compared to alfalfa forage prior to ensiling, ensiling decreased the $\mathrm{DM}$, protein, $\mathrm{pH}$, and WSC values and increased the number of LAB (Tables 1,2). After ensiling, the DM content of the treated silages was higher than that of the control silage, and the DM content of the CEGA and GALP silages was higher than that of the CELP silage $(P<0.05)$. The $\mathrm{pH}$ values of all the treated silages were lower than that of the untreated silage, while the $\mathrm{pH}$ of the CELP silage was lower than that of the CEGA and GALP silages $(P<0.05)$. The ammonia levels in the treated silages were lower than those in the control silage, while those in the CEGA silage were lower than those in the CELP and GALP silages $(P<0.05)$. The LAB counts were higher in treated silages than in the control silage $(P<0.05)$, while no differences were observed among the treated silages $(P>0.05)$ (Table 2$)$.

After ensiling, the treated silages showed higher lactic acid levels than the untreated silage $(P<0.05)$, particularly for the CELP silage, which was higher than that observed in the CEGA and GALP silages. The treated silages (CEGA and GALP) exhibited increased acetic acid levels compared to the control silage, while the CEGA silage showed higher acetic acid contents than the CELP and GALP silages $(P<0.05)$. No differences in the levels of propionic and butyric acids were observed among the treated silages $(P>0.05)$, while the levels of these acids were lower in the treated silages than in the untreated silage $(P<0.05)$.

The treated silages (CEGA, CELP, and GALP) exhibited lower NDF contents than the control silages $(P<0.05)$, where the NDF level was lower in the CELP silage than in the CEGA and GALP silages $(P<0.05)$. All treated silages had lower ADF contents than the

Table 1 Chemical composition of alfalfa forage prior to ensiling

\begin{tabular}{|c|c|c|c|c|c|c|c|c|}
\hline DM & $\mathrm{pH}$ & wSC & NH3-N & Protein & NDF & $A D F$ & Fat & LAB \\
\hline $36.9 \pm 0.73$ & $6.1 \pm 0.04$ & $69.2 \pm 1.12$ & $4.6 \pm 0.07$ & $24.6 \pm 0.23$ & $47.6 \pm 0.67$ & $36.7 \pm 0.44$ & $4.8 \pm 0.04$ & $6.4 \pm 0.08$ \\
\hline
\end{tabular}


Table 2 Fermentation characteristic and microbial counts of the alfalfa silages (g/kg of DM except as noted)

\begin{tabular}{|c|c|c|c|c|}
\hline & Control & CEGA & CELP & GALP \\
\hline DM g/100 g & $33.5 \pm 0.31^{c}$ & $35.9 \pm 0.41^{\mathrm{a}}$ & $35.0 \pm 0.20^{b}$ & $36.2 \pm 0.32^{\mathrm{a}}$ \\
\hline $\mathrm{pH}$ & $5.2 \pm 0.18^{\mathrm{a}}$ & $4.8 \pm 0.04^{b c}$ & $4.7 \pm 0.07^{c}$ & $4.9 \pm 0.09^{b}$ \\
\hline WSC g kgDM-1 & $13.0 \pm 0.73^{c}$ & $14.9 \pm 1.06^{b c}$ & $13.5 \pm 0.93^{\mathrm{a}}$ & $13.8 \pm 0.62^{b}$ \\
\hline \multicolumn{5}{|l|}{ Fermentation products } \\
\hline Ammonia (g kgDM-1) & $7.8 \pm 0.41^{a}$ & $4.6 \pm 0.29^{d}$ & $5.3 \pm 0.61^{b}$ & $5.0 \pm 0.25^{c}$ \\
\hline Lactic acid (g kgDM-1) & $30.7 \pm 1.17^{d}$ & $36.9 \pm 2.36^{c}$ & $51.2 \pm 2.41^{\mathrm{a}}$ & $45.5 \pm 2.04^{b}$ \\
\hline Acetic acid (g kgDM-1) & $12.6 \pm 1.48^{c}$ & $38.3 \pm 1.94^{\mathrm{a}}$ & $17.5 \pm 0.98^{b}$ & $18.4 \pm 1.09^{b}$ \\
\hline propionic acid (g kgDM-1) & $1.8 \pm 0.07^{\mathrm{a}}$ & $0.2 \pm 0.01^{b}$ & $0.2 \pm 0.06^{b}$ & $0.3 \pm 0.01^{b}$ \\
\hline Butyric acid (g kgDM-1) & $3.1 \pm 0.23^{a}$ & $0.0 \pm 0.00^{b}$ & $0.0 \pm 0.02^{b}$ & $0.1 \pm 0.04^{b}$ \\
\hline LAB $\left(\log c f u g^{-1} F M\right)$ & $7.5 \pm 0.16^{b}$ & $8.3 \pm 0.14^{a}$ & $8.5 \pm 0.08^{\mathrm{a}}$ & $8.5 \pm 0.12^{a}$ \\
\hline \multicolumn{5}{|l|}{ Nutrient composition } \\
\hline Crude protein & $21.7 \pm 0.09^{c}$ & $22.6 \pm 0.25^{\mathrm{a}}$ & $23.5 \pm 0.59^{a}$ & $23.3 \pm 0.02^{b}$ \\
\hline NDF & $43.1 \pm 1.70^{a}$ & $41.7 \pm 1.86^{b}$ & $40.2 \pm 2.05^{c}$ & $42.6 \pm 1.43^{b}$ \\
\hline ADF & $34.9 \pm 0.56^{a}$ & $32.3 \pm 0.98^{b}$ & $31.3 \pm 1.59^{b}$ & $33.3 \pm 0.36^{a b}$ \\
\hline Crude Fatty & $4.3 \pm 0.05^{a}$ & $4.3 \pm 0.03^{a}$ & $3.7 \pm 0.05^{b}$ & $3.7 \pm 0.04^{b}$ \\
\hline
\end{tabular}

CON untreated silage, CEGA silage treated with cellulase plus a-galactosidase, CELP silage treated with cellulase plus $L$. plantarum, GALP silage treated with a-galactosidase plus L. plantarum

$\mathrm{a}, \mathrm{b}, \mathrm{c}$ Means with different superscripts in the same row differ $(P<0.05)$

Table 3 Statistics of high-throughput sequencing data and the bacterial community diversity of alfalfa silage

\begin{tabular}{llllll}
\hline Treatments & Sobs & Shannon & Simpson & Chao & Ace \\
\hline Control & $32.0 \pm 9.54$ & $1.8 \pm 0.54$ & $0.3 \pm 0.17$ & $33.0 \pm 8.66^{\mathrm{b}}$ & $35.3 \pm 6.20^{\mathrm{b}}$ \\
CEGA & $29.0 \pm 3.46$ & $1.5 \pm 0.25$ & $0.3 \pm 0.08$ & $34.0 \pm 9.00^{\mathrm{ab}}$ & $34.4 \pm 9.20^{\mathrm{ab}}$ \\
CELP & $34.7 \pm 4.04$ & $1.5 \pm 0.03$ & $0.3 \pm 0.01$ & $38.8 \pm 6.33^{\mathrm{ab}}$ & $46.0 \pm 15.12^{\mathrm{ab}}$ \\
GALP & $39.0 \pm 7.00$ & $1.5 \pm 0.10$ & $0.3 \pm 0.02$ & $42.6 \pm 5.65^{\mathrm{a}}$ & $50.0 \pm 6.54^{\mathrm{a}}$ \\
\hline
\end{tabular}

CON untreated silage, CEGA silage treated with cellulase plus a-galactosidase, CELP silage treated with cellulase plus $L$. plantarum, GALP silage treated with a-galactosidase plus L. plantarum

a, b, c Means with different superscripts in the same column differ $(P<0.05)$

control silage $(P<0.05)$, with no significant differences observed between the treated silages $(P>0.05)$. The crude protein contents of the treated silages were higher than that of the control silage, and the CEGA silage showed lower levels of crude protein than the CELP and GALP silages $(P<0.05)$. No significant differences in crude protein levels were observed between the CELP and GALP silages $(P>0.05)$. The fat content in the control and CEGA silages was higher than that in the CELP and GALP silages $(P<0.05)$ (Table 2$)$.

\section{Sequence analysis of bacterial communities in alfalfa silages}

Based on Illumina sequencing of the V3-V4 region of the $16 \mathrm{~S}$ rRNA gene for bacteria in silage, an average of 34,095 \pm 3107 sequences were obtained from each sample, with an average length of $448 \pm 4$ bp per sequence. All sequences were sub-sampled to a size of 29,271 to limit sampling error. Finally, 69 OTUs were obtained that were assigned to 59 species, 45 genera, 30 families, 19 orders, 13 classes and 7 phyla. The tendency of the rarefaction curves to plateau indicates that sufficient sequencing depth of the silage bacterial communities was achieved (Additional file 1: Figure S1). With respect to the a-diversity indices, GALP showed higher Chao and Ace indices compared to that of the control silage $(P<0.05)$ (Table 3$)$.

\section{Clusters of bacterial communities between alfalfa silages} PCoA based on weighted UniFrac distances revealed distinct clusters between the control and additivetreated silages (Fig. 1), including for the non-additive-treated silage, enzyme-treated silage (CEGA), and silage treated with enzyme in combination with inoculant (CELP and GALP). Further analysis using 

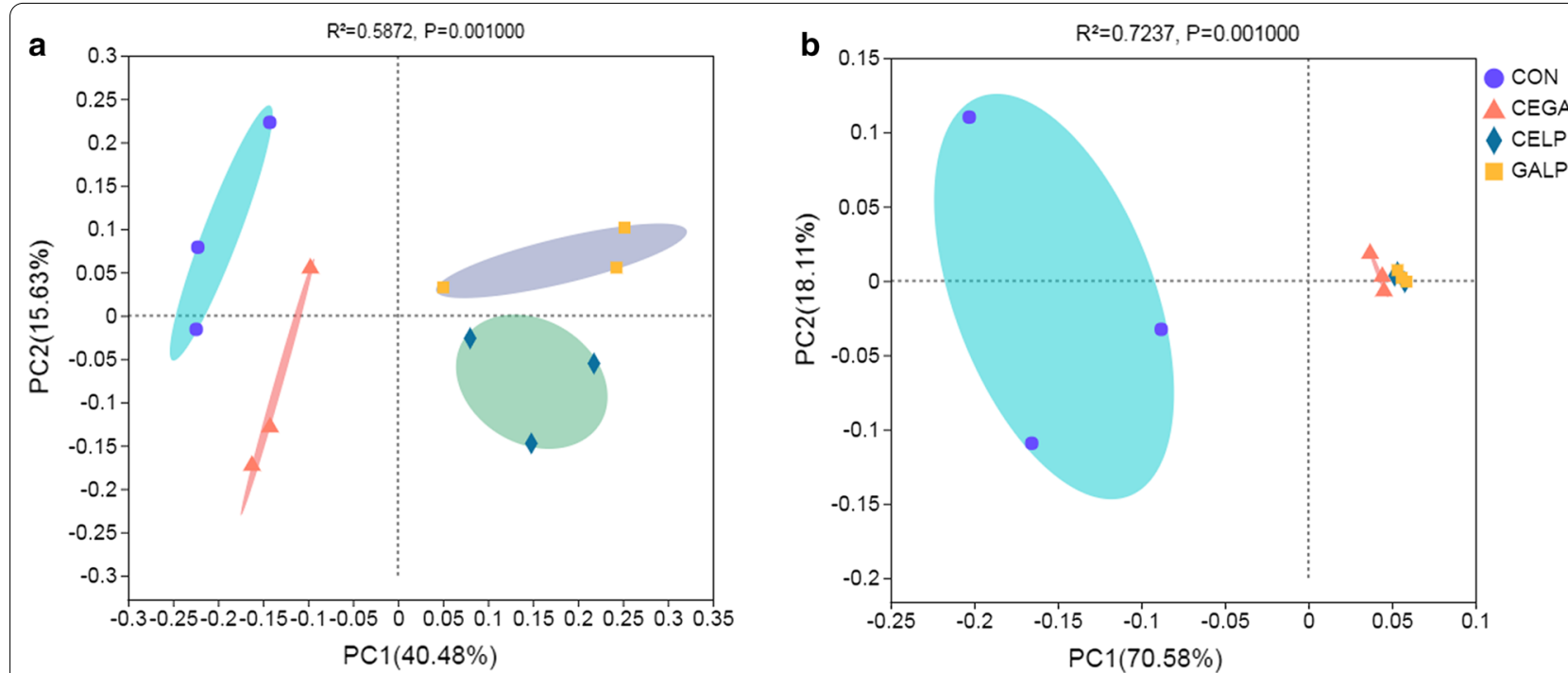

Fig. 1 Principal coordinate analysis (PCOA) of the bacterial communities based on unweighted (a) and weighted UniFrac (b) at the OTU level. CON untreated silage, CEGA cellulase plus a-galactosidase, CELP cellulase plus L. plantarum, GALP a-galactosidase plus L. plantarum

the Adonis test showed that the clusters were reliable $\left(\mathrm{R}^{2}=0.72, P=0.001\right)$. Venn diagram analysis showed that significant overlap occurs between the control silage and CEGA silages, with 32 OTUs shared by these two groups. The CELP and GALP silages were similar, with 38 OTUs shared by these two groups (Additional file 2: Figure S2). These results clearly indicate that the inoculants affected the bacterial community of the alfalfa silage.

\section{Bacterial composition of alfalfa silage}

At the phylum level, Firmicutes dominated the bacterial communities of the control silage, with an observed abundance of $88.28 \%$, followed by Proteobacteria and Actinobacteria, with observed abundances of 8.79 and $2.86 \%$, respectively. Firmicutes dominated the bacterial communities of all treated silages, with observed abundances of 95.01, 98.57, and 99.07\% observed in the CEGA, CELP and GALP silages, respectively. Proteobacteria was also observed in all treated silages at a low abundance (Fig. 2a).

At the class level, Bacilli and Clostridia were predominant in the control silage, with observed abundances of 51.26 and $37.01 \%$ respectively, while Bacilli dominated the bacterial communities of all treated silages, with abundances of 94.98, 98.53, and 97.66\% observed in the CEGA, CELP and GALP silages, respectively. Gammaproteobacteria were detected in all silages, with observed abundances of $8.79,4.82,1.22$, and $0.62 \%$ in the control, CEGA, CELP, and GALP silages, respectively. Actinobacteria was only detected in the control silage, with an observed abundance of $2.87 \%$ (Fig. 2b). The abundance of Bacilli in the control silage was lower than that in all the treated silages $(P<0.05)$. The abundances of Clostridia and Actinobacteria in the control silage were higher than those in all the treated silages $(P<0.05)$ (Additional file 3: Figure S3).

Bacterial composition changes in the silage were also observed at the genus (Fig. 2c, Additional file 4: Figure S4) and OTU (Additional file 5: Figure S5) levels. Eleven genera exhibited a relative abundance $>1 \%$ in the control silage. Among these genera, Garciella, Enterococcus, Lactobacillus and Pediococcus showed abundances of $30.21,24.54,12.11$, and $10.18 \%$, respectively. In addition, Clostridium_sensu_stricto_18 (1.82\%), Staphylococcus (1.81\%), Propionibacterium (2.84\%), and Anaerosporobacter (4.93\%) also exhibited abundances above $1 \%$.

In the CEGA silage, compared to the control silage, Lactobacillus and Pediococcus exhibited increased abundances of 49.64 and $35.31 \%$, respectively $(P<0.05)$. Weissella was also present in the CEGA silage at a relatively high abundance $(9.56 \%)$ compared to that in the control silage $(P<0.05)$ (Figs. 2c, 3).

The other three silages showed similar bacterial compositions, with Lactobacillus being the dominant genus at an abundances of 97.88 and $96.74 \%$ in the CELP and GALP silages, respectively. In addition, no genera were above a $1 \%$ abundance in these silages (Fig. 2c, Additional file 4: Figure S4).

Significant differences in the abundances of many bacterial taxa were observed between groups, as 


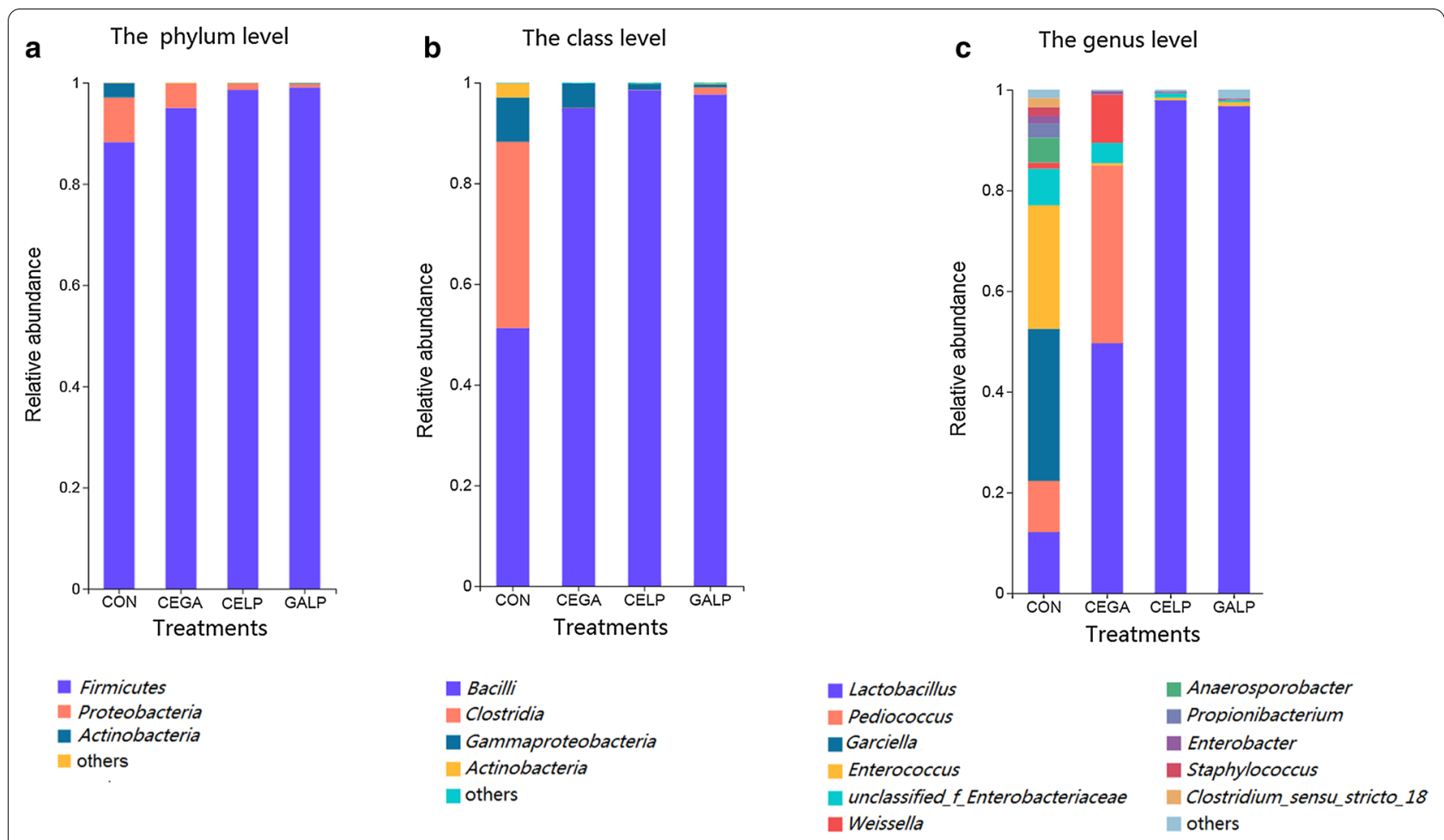

Fig. 2 Bacterial composition of alfalfa silage with different treatments (Control, CEGA, CELP, and GALP) at the phylum (a), class (b) and genus levels (c). Phyla, classes and genera with less than $1 \%$ overall relative abundance were summed and presented as "Others". CON untreated silage, CEGA cellulase plus a-galactosidase, CELP cellulase plus L. plantarum, GALP a-galactosidase plus L. plantarum

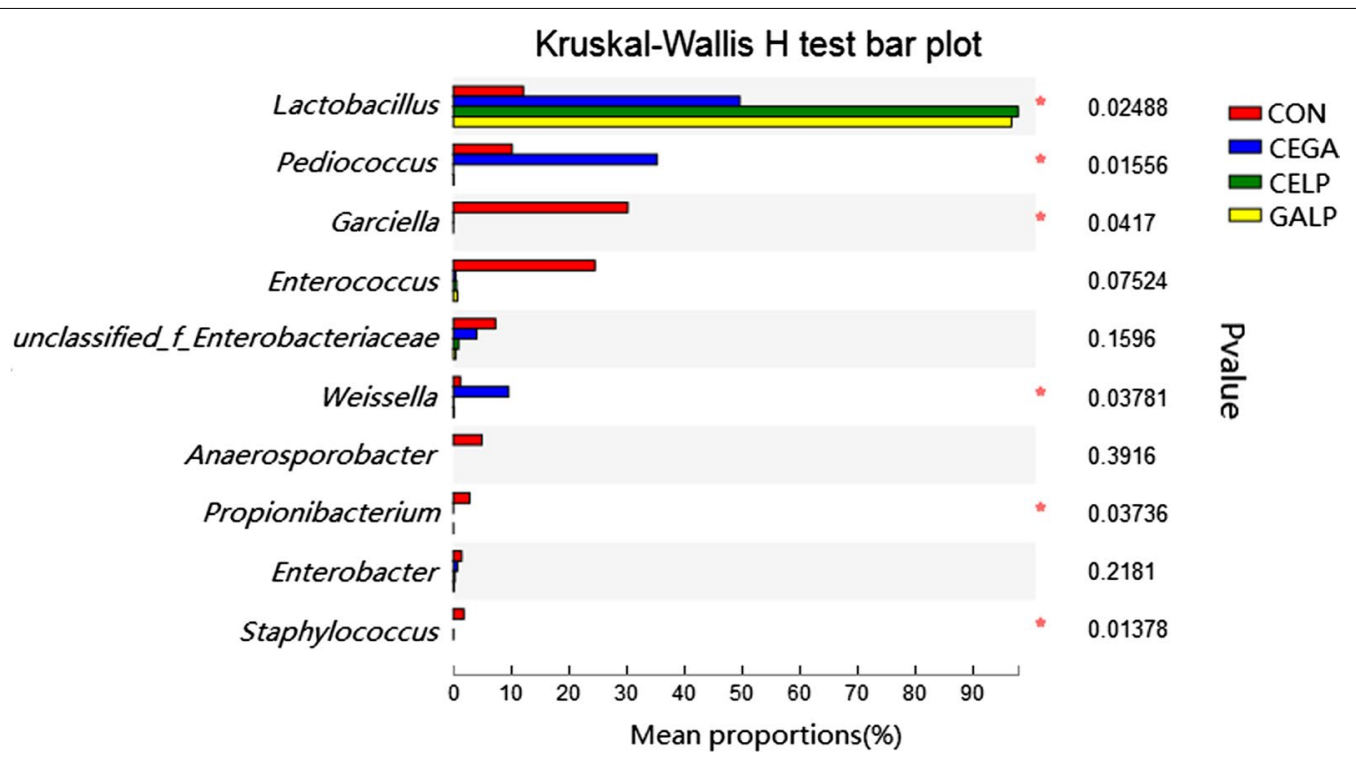

Fig. 3 Kruskal-Wallis $\mathrm{H}$ test of the bacterial community at the genus level. The top 10 genera are shown in the figure. CON untreated silage, CEGA cellulase plus a-galactosidase, CELP cellulase plus L. plantarum, GALP a-galactosidase plus L. plantarum

analysed by the Kruskal-Wallis $\mathrm{H}$ test $(P<0.05)$ (Fig. 3). The abundance of Lactobacillus in the control silage was lower than that in all treated silages (CEGA, CELP, and GALP) $(P<0.05)$. Furthermore, the abundance of Lactobacillus in the CELP and GALP silages was higher than that in the CEGA silage $(P<0.05)$. The abundance 
of Garciella was higher in the control silage than in all the treated silages $(P<0.05)$, while that of Pediococcus in the CEGA silage was higher than that in the control, CELP and CEGA silages $(P<0.05)$. In addition, the abundance of Propionibacterium in the control silage was higher than in the CEGA, CELP, and GALP silages $(P<0.05)$.

\section{Relationship between fermentation products and bacterial communities}

RDA was performed to evaluate the effects of bacterial composition on the fermentation products in alfalfa silages (Fig. 4). Mantel tests on the models were performed with a minimum of 999 permutations, and the multivariate regression was significant $(R=0.49$, $P=0.005)$, indicating a correlation between the bacterial composition and fermentation products. As demonstrated by RDA results, Lactobacillus was associated with the lactic acid content in the CELP and GALP silages, whereas Caeciella and Enterococcus were associated with the $\mathrm{pH}$ value and propionic and butyric acids contents in the control silage. In addition, Pediococcus and Weissella were associated with the acetic acid content in the CEGA silage.

\section{Discussion}

Effects of enzyme and enzyme + inoculant treatments on silage fermentation quality

The treatment of silage with enzymes (cellulase combined with galactosidase) alone or in combination with L. plantarum affected the LAB cfu of silage after 56 days. The increased organic acid levels in the alfalfa silages suggested that the enzyme treatments were markedly beneficial, especially enzyme plus inoculant treatments (cellulase plus L. plantarum and galactosidase plus $L$. plantarum) (Nadeau et al. 2000). Concurrently, enzymetreated (CEGA) silage exhibited increased acetic acid concentrations. Consistent with our results, Kung et al. (1991) observed increased acetic acid concentrations in cellulase plus pectinase-treated alfalfa silage, whereas a decreased acetic acid concentration was observed in alfalfa silage treated with cellulase (Nadeau et al. 2000). The decreased acetic acid levels indicate that more homolactic than heterolactic fermentation occurred in silage. The lactic acid concentration in the silage treated with inoculants + enzyme were higher than those in the silage treated with enzyme only, indicating that combined enzyme and inoculants treatment may be more beneficial than the enzyme alone treatment. These results indicate

\section{RDA on Genus level}

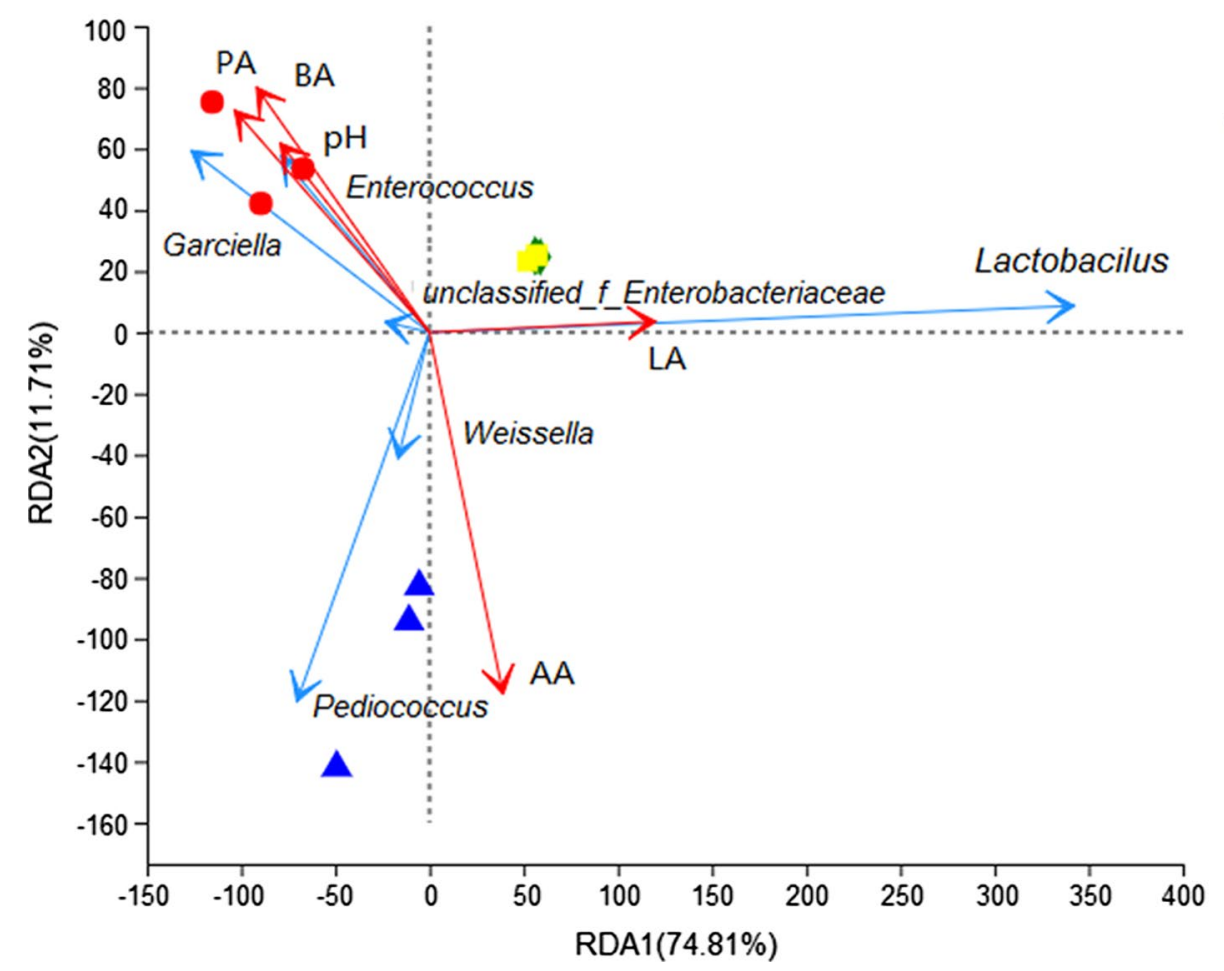

Fig. 4 Correlation analyses between microorganisms and fermentation products in alfalfa silage. $L A$ lactic acid, $A A$ acetic acid, PA propionic acid, BA butyric acid, CON untreated silage, CEGA cellulase plus a-galactosidase, CELP cellulase plus L. plantarum, GALP a-galactosidase plus L. plantarum 
that the addition of inoculants amplified the effect of the enzyme and led to a more rapid fermentation with lactic acid production. Overall, the treatment of alfalfa silage with enzymes or enzymes combined with inoculants clearly improved the ensiling characteristics, decreasing the $\mathrm{pH}$, ammonia levels, and butyric acid levels and increasing the DM and lactic acid levels. Consistent with our results, previous studies showed that fibrolytic enzyme treatment resulted in increased lactic acid levels and decreased $\mathrm{pH}$, butyric acid and ammonia levels compared with the control in the silages of various plants, such as lucerne, barley and orchardgrass (Dehghani et al. 2012; Zahiroddini et al. 2004; Nadeau et al. 2000). Notably, the addition of enzymes (CEGA, CELP, and GALP) as a whole increased protein levels, and decreased the NDF and ADF levels. On the one hand, the reduction of NDF and ADF levels increases the proportion of protein; on the other hand, the soluble sugars released by cellulose hydrolysis increase the number of LAB, which inhibits the growth of spoilage microorganisms and protein degradation by spoilage microorganisms. This finding indicated the degradation of the plant cell walls by fibrolytic enzymes (Muck et al. 2018), which is consistent with the results of a study of Lynch et al. (2014), who showed that fibrolytic enzymes decreased both NDF and ADF concentrations in alfalfa silage. Similarly, van Vuuren et al. (1989) observed that cell wall degrading enzymes decreased the NDF and ADF levels of grass silage. In other studies, the NDF, ADF and protein levels did not considerably change upon treatment with inoculants or inoculants plus enzyme (Fredeen et al. 1991; Kozelov et al. 2008), possibly due to a high DM content. Tengerdy et al. (1991) used cell wall degrading enzymes or a combination of these enzymes with LAB to ensile fresh cut and wilted alfalfa and showed that a cocktail of cellulase, hemicellulase and pectinase enzymes with a lactic acid bacteria inoculum containing Pediococcus, Lactobacillus and Streptococcus spp. is more effective in producing lactic acids and the enzyme treatments were more beneficial in terms of improving ensiling quality in fresh rather than wilted alfalfa, perhaps indicating that the high moisture conditions are favourable for enzyme hydrolysis.

\section{Bacterial communities in alfalfa silage}

Regarding the microbial diversity of silage treated with enzymes, relevant research is lacking. Therefore, the bacterial communities of alfalfa silage treated with enzymes and enzymes + inoculants were evaluated in the present study. Compared to untreated silage, the enzyme and combination of enzyme and inoculant treatments increased the total abundance of LAB in silage. In the untreated silage, several LAB, including Enterococcus, Pediococcus, Lactobacillus, and Weissella species accounted for $46.83 \%$ of the total abundance at the genus level. The enzymatic treatment of silage apparently increased the abundance of LAB to $94.54 \%$ at the genus level, including Lactobacillus (49.64\%), Pediococcus (35.31\%), and Weissella (9.56\%), which was approximately double that of the control silage. As discussed above, fibrolytic enzymes in silage can degrade fibre to glucose, which can be used by LAB, as the results showed. The increase of glucose in silage due to treatment with fibrolytic enzymes was showed in lucerne, corn and Italian ryegrass (Dehghani et al. 2012; Shepherd et al. 1995; Selmer-Olsen et al. 1993; Shepherd and Kung 1996).

Lactic acid bacteria (LAB) are important for good quality silage owing to their production of organic acids, primarily lactic acids. As shown in the present study, the high abundance of LAB led to the sufficient production of organic acids and greatly reduced the silage $\mathrm{pH}$ (Table 1 ). Lactic acid bacteria (LAB) can also produce antimicrobial substances, such as bacteriocins and reuterin, which inhibit other spoilage bacteria (Klaenhammer 1988). In the present study, compared to the control silage, the disappearance of the class Clostridia in the both enzyme and inoculants-treated silages may be a result of the high level of LAB, a mechanism that was confirmed by the observed of bacteriocin production (Flythe and Russell 2004; Marcinakova and Laukova 2004).

Lactobacillus was present at a high abundance in the enzyme-treated silage and exhibited absolute dominance in silages treated with enzyme plus inoculant (CELP and GALP). The dominance of Lactobacillus, leading to the elimination of native bacteria and decreased diversity of the bacterial community in silage treated with inoculants, was also observed in other studies ( $\mathrm{Li}$ and Nishino 2011; Parvin et al. 2010; Guo et al. 2018). Lactobacillus is a complex bacterial genus comprising both homofermentative and heterofermentative LAB. Depending on the species, homofermentative $\mathrm{LAB}$ can produce lactic acid, while heterofermentative LAB can produce both lactic and acetic acids (Muck et al. 2018). Corresponding to the absolute dominance of Lactobacillus, the significantly higher lactic acid content in the CELP and GALP silages than that in the control and enzyme-treated silages indicates that the increase in Lactobacillus is more effective for the production of lactic acid than other LAB species.

The treatment of cellulose $+L$. plantarum and a-galactosidase $+L$. plantarum led to the absolute domination by Lactobacillus in the alfalfa silage bacterial community, which was similar to the L. plantarumtreated alfalfa silage observed in previous studies, which also showed the dominance of Lactobacillus (Bao et al. 2016; Zheng et al. 2017; Yang et al. 2019). These results indicate the active growth of Lactobacillus in the $L$. 
plantarum-treated alfalfa silage, which may not be affected by enzyme treatment to some extent.

Bacteria of the genus Bacillus as well as Enterobacteriaceae species, such as those of the genus Enterobacter, were also clearly present in the untreated silage and exhibited decreased abundances in the treated silages. These bacteria can produce 2,3-butanediol by expending sugars needed by LAB (McDonald 1991), which may inhibit the growth of LAB in untreated control silage. The same phenomenon was observed for Anaerosporobacter species, which also ferment various carbohydrates to produce acetic and formic acids (Jeong et al. 2007). Aeriscardovia was present in silages treated with inoculants plus enzyme. Aeriscardovia, which was first isolated from a porcine caecum (Simpson et al. 2004), belongs to the family Bifidobacteriaceae, members of which can ferment a variety of carbohydrates to organic acids, such as acetic and lactic acids (Biavati and Mattarelli 2006).

\section{Correlation of bacterial community with fermentation quality}

RDA results showed that some bacterial genera were correlated with the fermentation indices, such as the positive correlation of Lactobacillus with lactic acids, Caeciella and Enterococcus with $\mathrm{pH}$, propionic acid and butyric acid, and Pediococcus with acetic acid. Lactobacillus is the genus that is typically present in the highest abundance in silages treated with $\mathrm{LAB}$, and it contributes the most to the production of lactic acids and the decline in pH during fermentation (Li et al. 2019; Zheng et al. 2017; $\mathrm{Ni}$ et al. 2017; Cai et al. 2020; Keshri et al. 2018). Furthermore, the correlation between Lactobacillus and lactic acids has been in other studies (Yang et al. 2019; Su et al. 2019).

Pediococcus, Enterococcus and Weissella were predominant in the enzyme-treated silage, which was consistent with the high level of acetic acid observed in this silage. As a genus of facultative heterofermentative LAB, Pediococcus can produce lactic acid by fermentation of hexoses and can also produce lactic and acetic acids via the fermentation of pentose (Muck et al. 2018). Enterococcus is also a genus of facultative heterofermentative bacteria. The occurrence of these two bacteria may explain the high acetic acid levels observed in the enzyme-treated (CEGA) silages. Weissella, which was present at a specific abundance in enzyme added silage (CEGA) silage, is a heterofermentative $\mathrm{LAB}$ that also contributed to the production of lactic and acetic acids. Although Enterococcus was present in the control silage, the low acetic acid levels in the control silage may be caused by the low abundance of LAB as a whole and the presence of Garciella, which can utilize organic acids as a fermentation substrate (Miranda-Tello et al. 2003).
The ammonia, propionic acid, and butyric acid levels in the control silage were distinctly higher than those in the treated silage. These substances can be produced by Garciella species, which were predominant in the untreated silage and absent in the treated silages. Garciella belongs to Clostridia, and was previously detected in alfalfa silage using a specific primer set to amplify the $16 \mathrm{~S}$ rRNA gene from Clostridia species (Zheng et al. 2017). In addition to fermenting sugars to produce lactic, acetic, and butyric acids, Garciella species are capable of utilizing organic acids, such as lactic acid to produce butyric acid, and can also produce hydrogen sulphide by reducing thiosulphate and ammonium by reducing nitrate (Miranda-Tello et al. 2003). Both butyric acid and ammonium are not considered to be desirable matter in silage.

Taken together, these findings indicate that the enzyme and enzyme plus LP treatments improved the silage fermentation quality, which decreased $\mathrm{pH}$ and ammonia levels and increased lactic acid levels. The nutritional value was also improved by preserving more DM and crude protein and decreasing the NDF level. The bacterial communities of the alfalfa silages exhibited changes as a result of the enzyme treatment, as revealed by highthroughput sequencing. Enzymatic treatment of alfalfa resulted in the predominance of several LAB genera in the silage, including Lactobacillus, Pediococcus, Enterococcus and Weissella, but the enzyme combined with LP treatment greatly increased the abundance of Lactobacillus in the alfalfa silage. The relationship between the bacterial community of the silage and ensiling characteristics was also confirmed in the present study. Therefore, the results of the present study support the treatment of silage with enzymes combined with LP, which showed a high fermentation quality and dominance of Lactobacillus in the alfalfa silage.

\section{Supplementary Information}

The online version contains supplementary material available at https://doi. org/10.1186/s13568-020-01158-5.

Additional file 1: Figure S1. Rarefaction curves showing the OUT diversity in alfalfa silages. CON untreated silage, EN silages treated ith cellulose plus a-galactosidase, LP silage treated with L. plantarum, ENLP silage treated with cellulase plus a-galactosidase plus L. plantarum.

Additional file 2: Figure S2. Venn showing the shared and unique OUT of bacterial communities in different treatments of alfalfa silage. CON untreated silage, CEGA silages treated with cellulase plus a-galactosidase, CELP silages treated with cellulase plus L. plantarum, GALP silages treated with a-galactosidase plus L. plantarum.

Additional file 3: Figure S3. Kruskal-Wallis $\mathrm{H}$ test of bacterial commu nity at class level. The top 5 classes were accounted in the figure. CON untreated silage, CEGA silages treated with cellulase plus a-galactosidase, CELP silages treated with cellulase plus L. plantarum, GALP silages treated with a-galactosidase plus L. plantarum.

Additional file 4: Figure S4. Community barplot analysis showing bacterial composition of the alfalfa silage at genus level. CON untreated 
silage, CEGA silages treated with cellulase plus a-galactosidase, CELP silages treated with cellulase plus L. plantarum, GALP silages treated with a-galactosidase plus L. plantarum.

Additional file 5: Figure S5. Community barplot analysis showing bacterial composition of the alfalfa silage at OUT level. CON untreated silage, CEGA silages treated with cellulase plus a-galactosidase, CELP silages treated with cellulase plus $L$. plantarum, GALP silages treated with a-galactosidase plus L. plantarum.

\section{Acknowledgements}

Not applicable.

\section{Authors' contributions}

$\mathrm{ZH}$ and DM conceived and designed the experiments. ZH, HN, JY, JC, SL, and SZ performed the experiments. ZH, HN, and QT analysed the data and contributed reagents/materials/analysis tools and prepared figures and/or tables. DM and ZH authored or reviewed drafts of the paper. All authors read and approved the final manuscript.

\section{Funding}

This work was funded by a grant from the Natural Science Foundation of Inner Mongolia Autonomous Region (Nos. 2018 MS03022 and 2018 LH03013), the First Level Training Project of Inner Mongolia Autonomous Region "Prairie Talent Project"Youth Innovation and Entrepreneur Talents (Q2017022) and the Open Project Program of Inner Mongolia Key Laboratory of Toxicant Monitoring and Toxicology (MDK2018031).

\section{Availability of data and materials}

All data generated or analysed during this study are included in this published article and its additional files. Sequence datasets for all the samples were deposited in the NCBI Database under accession number PRJNA522947.

\section{Ethics approval and consent to participate}

This article does not contain any studies with human participants or animals performed by any of the authors.

\section{Consent for publication}

Not applicable.

\section{Competing interests}

The authors declare that they have no competing interests.

\section{Author details}

${ }^{1}$ College of Animal Science and Technology, Northeast Agricultural University, Harbin, People's Republic of China. ${ }^{2}$ College of Animal Science and Technology, Inner Mongolia University for Nationalities, Tongliao, People's Republic of China.

Received: 22 May 2020 Accepted: 7 December 2020 Published online: 06 January 2021

\section{References}

Arriola KG, Kim SC, Adesogan AT (2011) Effect of applying inoculants with heterolactic or homolactic and heterolactic bacteria on the fermentation and quality of corn silage. J Dairy Sci 94:1511-1516

AOAC (2000) Official methods of analysis, 17th edn. Association of Official Analytical Chemist, Arlington, VA

Bao W, Mi Z, Xu H, Zheng Y, Kwok LY, Zhang H, Zhang W (2016) Assessing quality of Medicago sativa silage by monitoring bacterial composition with single molecule, real-time sequencing technology and various physiological parameters. Sci Rep 6:28358

Biavati B, Mattarelli P (2006) The family Bifidobacteriaceae. Springer, New York

Bolger AM, Marc L, Bjoern U (2014) Trimmomatic: a flexible trimmer for Illumina sequence data. Bioinformatics 30(15):2114-2120

Cai Y, Du Z, Yamasaki S, Nguluve D, Oya T (2020) Community of natural lactic acid bacteria and silage fermentation of corn stover and sugarcane tops in Africa. Asian Austral J Anim 33(8):1252-1264
Caporaso JG, Kuczynski J, Stombaugh J, Bittinger K, Bushman FD, Costello EK Fierer N, Pena AG, Goodrich JK, Gordon Jl, Huttley GA, Kelley ST, Knights D, Koenig JE, Ley RE, Lozupone CA, McDonald D, Muegge BD, Pirrung M, Reeder J, Sevinsky JR, Tumbaugh PJ, Walters WA, Widmann J, Yatsunenko T, Zaneveld J, Knight R (2010) QIIME allows analysis of high-throughput community sequencing data. Nat Methods 7:335-336

Contreras-Govea FE, Muck RE, Mertens DR, Weimer PJ (2011) Microbial inoculant effects on silage and in vitro ruminal fermentation, and microbial biomass estimation for alfalfa, BMR corn, and corn silages. Anim Feed Sci Technol 163:2-10

Cunningham SM, Nadeau P, Castonguay Y, Laberge S, Volenec JJ (2003) Raffinose and stachyose accumulation, galactinol synthase expression, and winter injury of contrasting alfalfa germplasms. Crop Sci 43:562-570

Dehghani MR, Weisbjerg MR, Hvelplund T, Kristensen NB (2012) Effect of enzyme addition to forage at ensiling on silage chemical composition and NDF degradation characteristics. Livest Sci 150:51-58

Dunière L, Sindou J, Chaucheyras-Durand F, Chevallier I, Thévenot-Sergentet D (2013) Silage processing and strategies to prevent persistence of undesirable microorganisms. Anim Feed Sci Tech 182:1-15

Drouin P, Tremblay J, Chaucheyras-Durand F (2019) Dynamic succession of microbiota during ensiling of whole plant corn following inoculation with Lactobacillus buchneri and Lactobacillus hilgardii alone or in combination. Microorganisms 7:595

Edgar RC, Haas BJ, Clemente JC, Christopher Q, Rob K (2011) UCHIME improves sensitivity and speed of chimera detection. Bioinformatics 27:2194-2200

Flythe MD, Russell JB (2004) The effect of $\mathrm{pH}$ and a bacteriocin (bovicin HC5) on Clostridium sporogenes MD1, a bacterium that has the ability to degrade amino acids in ensiled plant materials. FEMS Microbiol Ecol 47:215-222

Fredeen AH, McQueen RE, Browning DA (1991) Effects of enzymes and nutrients in a bacterial inoculant on quality of timothy or alfalfa silage and dairy cow performance. Can J Anim Sci 71(3):781-791

Guo XS, Ke WC, Ding WR, Ding LM, Xu DM, Wang WW, Zhang P, Yang FY (2018) Profling of metabolome and bacterial community dynamics in ensiled Medicago sativa inoculated without or with Lactobacillus plantarum or Lactobacillus buchneri. Sci Rep 8:357

Garro MS, de Valdez GF, Oliver G, de Giori GS (1996) Purification of cx-galactosidase from Lactobacillus fermenturn. J Biotechnol 45:103-109

Jeong H, Lim YW, Yi H, Sekiguchi Y, Kamagata Y, Chun J (2007) Anaerosporobacter mobilis gen. nov., sp. nov., isolated from forest soil. Int I Syst Evol Microbiol 57:1784-1787

Keshri J, Chen Y, Pinto R, Kroupitski Y, Weinberg ZG, Sela S (2018) Microbiome dynamics during ensiling of corn with and without Lactobacillus plantarum inoculant. Appl Microbiol Biotechnol 102(9):4025-4037

Kiełbasa A, Krakowska A, Rafińska K, Buszewski B (2019) Isolation and determination of saponin hydrolysis products from Medicago sativa using supercritical fluid extraction, solid-phase extraction and liquid chromatography with evaporative light scattering detection. J Sep Sci 42(2):1-24

Klaenhammer TR (1988) Bacteriocins of lactic acid bacteria. Biochimie 70:337-349

Kung L, Tung RS, Maciorowski KG, Buffum K, Knutsen K, Aimutis WR (1991) Effects of plant cell-wall-degrading enzymes and lactic acid bacteria on silage fermentation and composition. J Dairy Sci 74:4284-4296

Kung L, Taylor CC, Lynch MP, Neylon JM (2003) The effect of treating alfalfa with Lactobacillus buchneri 40788 on silage fermentation, aerobic stability, and nutritive value for lactating dairy cows. J Dairy Sci 86:336-343

Kozelov LK, lliev F, Hristov AN, Zaman S, Mcallister TA (2008) Effect of fibrolytic enzymes and an inoculant on in vitro degradability and gas production of low-dry matter alfalfa silage. J Sci Food Agr 88:2568-2575

LiY, Nishino N (2011) Bacterial and fungal communities of wilted Italian ryegrass silage inoculated with and without Lactobacillus rhamnosus or Lactobacillus buchneri. Lett Appl Microbiol 52:314-321

Li P, Zhang Y, Gou W, Cheng Q, Bai S, Cai Y (2019) Silage fermentation and bacterial community of bur clover, annual ryegrass and their mixtures prepared with microbial inoculant and chemical additive. Anim Feed sci Tech 247:285-293

Lynch JP, Jin L, Lara EC, Baah J, Beauchemin KA (2014) The effect of exogenous fibrolytic enzymes and a ferulic acid esterase-producing inoculant on the fibre degradability, chemical composition and conservation characteristics of alfalfa silage. Anim Feed Sci Tech 193:21-31 
Marcinakova M, Laukova A (2004) Probiotic properties of Enterococcus faecium EF9296 strain isolated from silage. Acta Vet Brno 73:513-519

McDonald P (1991) The biochemistry of silage. Wiley, Chichester

Mital BK, Shallenberger RS, Steinkraus KH (1973) a-Galactosidase activity of Lactobacilli. Appl Microbial 26:783-788

Miranda-Tello E, Fardeau ML, Sepúlveda J, Fernández L, Cayol JL, Thomas P, Ollivier B (2003) Garciella nitratireducens gen. nov., sp. nov., an anaerobic, thermophilic, nitrate- and thiosulfatereducing bacterium isolated from an oilfield separator in the Gulf of Mexico. Int J Syst Evol Microbiol 53:1509-1514

Muck RE, Nadeau EMG, McAllister TA, Contreras-Govea FE, Santos MC, Kung JL (2018) Silage review: recent advances and future uses of silage additives. J Dairy Sci 101:3980-4000

Nadeau EM, Buxton DR, Russell JR, Allison MJ, Young JW (2000) Enzyme, bacterial inoculant, and formic acid effects on silage composition of orchardgrass and alfalfa. J Dairy Sci 83:1487-1502

Ni K, Wang F, Zhu B, Yang J, Zhou G, Pan Y, Tao Y, Zhong J (2017) Effects of lactic acid bacteria and molasses additives on the microbial community and fermentation quality of soybean silage. Bioresource Technol 238:706-715

Owens VN, Albrecht KA, Muck RE, Duke SH (1999) Protein degradation and fermentation characteristics of red clover and alfalfa silage harvested with varying levels of total nonstructural carbohydrates. Crop Sci 39:1873-1880

Oliveira AS, Weinberg ZG, Ogunade IM, Cervantes AAP, Arriola KG, Jiang Y, Kim D, Li X, Gonçalves MCM, Vyas D, Adesogan AT (2017) Meta-analysis of effects of inoculation with homofermentative and facultative heterofermentative lactic acid bacteria on silage fermentation, aerobic stability, and the performance of dairy cows. J Dairy Sci 100:4587-4603

Parvin S, Wang C, Li Y, Nishino N (2010) Effects of inoculation with lactic acid bacteria on the bacterial communities of Italian ryegrass, whole crop maize, guinea grass and rhodes grass silages. Anim Feed Sci Technol 160:160-166

Pecetti L, Biazzi E, Tava A (2010) Variation in saponin content during the growing season of spotted medic [Medicago arabica (L.) Huds.]. J Sci Food Agric 90:2405-2410

Rafińska K, Pomastowski P, Wrona O, Górecki R, Buszewski B (2017) Medicago sativa as a source of secondary metabolites for agriculture and pharmaceutical industry. Phytochem Lett 20:520-539

Schloss PD, Westcott SL, Ryabin T, Hall JR, Hartmann M, Hollister EB, Lesniewski RA, Oakley BB, Parks DH, Robinson CJ, Sahl JW, Stres B, Thallinger GG, Van Horn DJ, Weber CF (2009) Introducing Mothur: open source, platformindependent, community-supported software for describing and comparing microbial communities. Appl Environ Microbiol 75:7537-7541

Selmer-Olsen I, Henderson AR, Robertson S, Mcginn R (1993) Cell wall degrading enzymes for silage. 2. Aerobic stability of enzyme-treated laboratory silages. Grass Forage Sci 48:55-63
Sheperd AC, Maslanka M, Quinn D, Kung L (1995) Additives containing bacteria and enzymes for alfalfa silage. J Dairy Sci 78:565-572

Shepherd AC, Kung JL (1996) Effects of an enzyme additive on composition of corn silage ensiled at various stages of maturity. J Dairy Sci 79:1767-1773

Simpson PJ, Ross RP, Fitzgerald GF, Stanton C (2004) Bifidobacterium psychraerophilum sp. nov. and Aeriscardovia aeriphila gen. nov., sp. nov., isolated from a porcine caecum. Int I Syst Evol Microbiol 54:401-406

Su R, Ni K, Wang T, Yang X, Zhang J, Liu Y, Shi W, Yan L, Jie C, Zhong J (2019) Effects of ferulic acid esterase-producing Lactobacillus fermentumand cellulase additives on the fermentation quality and microbial community of alfalfa silage. PeerJ 7:e7712

Tava A, Odoardi M (1996) Saponins from medicago spp.: chemical characterization and biological activity against insects. Adv Exp Med Biol 405(1):97-109

Tengerdy RP, Weinberg ZG, Szakacs G, Wu M, Linden JC, Henk LL, Johnson DE (2010) Ensiling alfalfa with additives of lactic acid bacteria and enzymes. J Sci Food Agr 55:215-228

Tengerdy RP, Weinberg ZG, Szakacs G, Wu M, Linden JC, Henk LL, Johnson DE (1991) Ensiling alfalfa with additives of lactic acid bacteria and enzymes. J Sci Food Agric 55:215-228

Van Soest PJ, Robertson JB, Lewis BA (1991) Methods for dietary fiber, neutral detergent fiber, and nonstarch polysaccharides in relation to animal nutrition. J Dairy Sci 74:3583-3597

Vuuren AMV, Bergsma KF, Frol-Keamer F, Beers JACV (1989) Effects of addition of cell wall degrading enzymes on the chemical composition and the in sacco degradation of grass silage. Grass Forage Sci 44:223-230

Yang L, Yuan X, Li J, Dong Z, Shao T (2019) Dynamics of microbial community and fermentation quality during ensiling of sterile and nonsterile alfalfa with or without Lactobacillus plantarum inoculant. Bioresource Technol 275:280-287

Zahiroddini H, Baah J, Absalom W, McAllister TA (2004) Effect of an inoculants and hydrolytic enzymes on fermentation and nutritive value of whole crop barley silage. Anim Feed Sci Technol 117:317-330

Zheng ML, Niu DZ, Jiang D, Zuo SS, Xu CC (2017) Dynamics of microbial community during ensiling direct-cut alfalfa with and without $L A B$ inoculant and sugar. J Appl Microbiol 122:1456-1470

\section{Publisher's Note}

Springer Nature remains neutral with regard to jurisdictional claims in published maps and institutional affiliations.

\section{Submit your manuscript to a SpringerOpen ${ }^{\circ}$ journal and benefit from:}

- Convenient online submission

- Rigorous peer review

- Open access: articles freely available online

- High visibility within the field

Retaining the copyright to your article

Submit your next manuscript at springeropen.com 